\title{
THE EFFECT OF GENDER AND BREED ON SOME PROPERTIES OF PIG MEAT
}

\author{
N. Stanišić ${ }^{1}$ M. Petrović ${ }^{2}$ Č. Radović ${ }^{1}$, M. Gogić ${ }^{1}$, N. Parunović ${ }^{3}$, S. \\ Stajić $^{2}$, M. Petričević ${ }^{1}$ \\ ${ }^{1}$ Institute for Animal Husbandry, Autoput 16, 11080, Belgrade-Zemun, Serbia \\ ${ }^{2}$ University of Belgrade, Faculty of Agriculture, Nemanjina 6, 11080, Belgrade-Zemun, Serbia \\ ${ }^{3}$ Institute of Meat Hygiene and Technology, Kaćanskog 13, 11000, Belgrade, Serbia \\ Corresponding author: nikola0135@yahoo.com \\ Original scientific paper
}

Abstract: This study was conducted to investigate differences in characteristics of muscles from male and female fatteners from Mangalitsa and Swedish Landrace pig breed. The research was carried out on three muscles: $m$. longissimus thoracis et lumborum, $m$. gluteus medius and $m$. triceps brachii. Compared to the Swedish Landrace, it was found out that the meat of the Mangalitsa had considerably higher intramuscular fat content $(\mathrm{p}<0.05)$. The highest intramuscular fat content was determined in male fatteners of Mangalitsa in $\mathrm{m}$. gluteus medius $(6.81 \%)$ and the lowest in female fatteners of Landrace pig breed in the longissimus muscle (1.12\%). As for technological quality of meat, after cooking, meat from Mangalitsa pig had greater cooking weight loss compared to Landrace and also lower shear force (SF) values for longissimus, but higher SF values for gluteus muscle. Gender had no statistically significant effect on technological meat quality. It can be concluded, on the base of the results, that the Mangalitsa pig, had favourable meat quality traits, which are very desired for production of traditional meat products of high quality. quality

Key words: Mangalitsa, gender, meat, chemical composition, technological

\section{Introduction}

Quality of meat within species can be influenced by the origin of the animals, the feed materials, slaughter and chilling procedures, storage conditions, muscle type, etc. Meat and meat products from autochthonous pigs are highly appreciated by consumers because of their high sensory quality (Živković et al., 2012; Stanišić et al., 2013).

In Republic of Serbia three native autochthonous pig breeds are registered: Mangalitsa, Moravka and Resavka. First one is the most present and the last one 
the least (Petrović et al., 2010). Mangalitsa is characterized by dark colour, robust constitutions and slower growth rate with higher adiposity and reduced lean deposition in comparison to modern white pigs. For this reason, producers have lost their interest in producing these pig breeds and their numbers have declined considerably to the point of extinction. However, fat is one of the most important raw material derived from slaughtered pigs and one of the main ingredients for the production of quality meat products (Stanišić et al., 2012), especially in the production of high priced cured meat products, such as proscuito and dry-cured ham (Antequera et al., 1992). Fat contributes to the juiciness of dry-cured hams and due to the lipolytic and oxidative processes that occurs during the curing treatment, it also influences the development of the aroma (López et al., 1992).

The present study was undertaken to evaluate the differences in proximate composition, colour, technological and physicochemical characteristics of meat of Mangalitsa and Swedish Landrace pigs.

\section{Materials and Methods}

Trial was carried out on the farm, in slaughterhouse and laboratory of the Institute for Animal Husbandry (Belgrade, Serbia) on two different pig breeds: Mangalitsa $(n=16)$ and Sweidish Landrace $(n=16)$. Each group of pigs was divided into two equal groups according to gender. The diet of animals consisted of concentrated commercial feed administered "ad libitum" (Table 1). Water was provided using automatic feeding troughs. Pigs were slaughtered with average age of 12 months (Manglaitsa) and 6 months (Landrace), when they attained their target slaughter weight of $110 \mathrm{~kg}$.

Table 1. Composition of feed used in the fattening of pigs

\begin{tabular}{|l|c|c|}
\hline Mixture ingredients (\%) & First 7 days of fattening & To the end of fattening \\
\hline Corn - dry & 67.50 & 68.75 \\
\hline Livestock flour & 10.00 & 10.00 \\
\hline Soybean meal & 14.80 & 14.80 \\
\hline Sunflower meal & 2.00 & 2.00 \\
\hline Soybean oil & 2.50 & 1.25 \\
\hline Lime & 1.30 & 1.30 \\
\hline Monocalcium phosphate & 0.80 & 0.80 \\
\hline Salt & 0.45 & 0.45 \\
\hline Premix & 0.50 & 0.50 \\
\hline Synthetic lysine & 0.05 & 0.05 \\
\hline
\end{tabular}


Animals were denied food $12 \mathrm{~h}$ prior to slaughtering, but had free access to water. After slaughtering, pig carcasses were processed using standard techniques. After hair removal and evisseration, carcasses were cut into carcass sides and put in cooling chamber at temperature of $2-4^{\circ} \mathrm{C}$ for next 24 hours. After chilling, all muscle samples ( $m$. longissimus thoracis et lumborum, $m$. gluteus medius, $m$. triceps brachii) were removed from the left carcasses side.

Analyses of $\mathrm{pH}$ value, water holding capacity, shear force and cooking loss, were performed on fresh meat samples, one day after slaughter and chilling of carcass sides. Chemical analyses were performed on defrosted meat samples, subsequent to freezing at $-18^{\circ} \mathrm{C}$.

In all samples, main proximate composition was determined: moisture content by drying of samples at temperature of $105^{\circ} \mathrm{C}$ to a constant mass, quantity of intramuscular fat by method of extraction according to Soxlet (with petrol-ether as solvent), quantity of proteins using method according to Kjeldahl and multiplying by factor 6,25 and quantity of mineral matters (ashes) by burning of samples at temperature of $550-600^{\circ} \mathrm{C}$ to a constant mass $(A O A C, 1990)$.

Water holding capacity (WHC) was done according to method by Grau and Hamm (Grau et al., 1953). pH value of meat was measured using pH-meter Hanna, HI 83141 (Hanna Instruments, USA). Cooking loss was determined in the following way: sample of size of $3 \times 4 \times 2 \mathrm{~cm}$ is weighed and put into glass with boiling water and cooked for 10 minutes; difference in mass of sample before and after cooking represents loss of mass during heat treatment and it is expressed in percentages. Samples used for determination of cooking loss were also used for determination of meat shear force $(\mathrm{kg})$ : muscles have been cut to parts of size of $1 \mathrm{x} 1 \mathrm{~cm}$ in the direction of muscle fibre extension; meat tenderness, expressed by shear force, was measured on Volodkevich apparatus (Volodkevich, 1938); higher values read out on the apparatus marked higher values of shear force, i.e. firmer meat.

In order to determine the effect of gender and breed on meat quality characteristics, a 2x2 factorial design was performed using General Linear Model procedure of SPSS 15.0 software (IBM Statistics). Interactions between gender and breed were not significant and therefore are not shown in this paper. All results are expresed as mean \pm standard deviation.

\section{Results and Discussion}

Proximate composition of meat samples from male and female fatteners of Mangalitsa and Swedish Landrace breed is presented in Table 2. From the literature data it is known that the percentage of intramuscular fat influence meat appearance (marbling) and also have an effect on meat tenderness, juiciness and flavour. Regarding this, for longissimus muscle, an optimum level of $2 \%$ of 
intramuscular fat has been proposed (Bejerholm and Barton-Gade, 1986). In all analysed meat samples, content of intramuscular fat was statistically significantly higher in Mangalitsa compared with Landrace. That tendency of autochotonous pig breeds to have higher intramuscular fat content than improved breeds is well known (Estévez et al., 2003; Franci et al., 2005; Petrović et al., 2010; Parunović et al., 2013). Regarding gender of animals, in longissimus and gluteus muscle, male fatteners had higher share of fat compared with females, while in triceps muscle, female fatteners had statisticly higher content of intramuscular fat. The highest intramuscular fat content was determined in male fatteners of Mangalitsa in m. gluteus medius $(6.81 \%)$ and the lowest in female fatteners of Landrace in the longissimus muscle (1.12\%).

Effect of breed on reduction of fat content probably influenced the increased moisture content, which was statistically significantly higher in gluteus muscle of Landrace compared with Mangalitsa. The higher content of ash was established longissimus muscle of Landrace. Content of protein did not differ significantly between the analysed groups.

Table 2. Proximate composition of meat from two pig breeds

\begin{tabular}{|c|c|c|c|c|c|c|}
\hline \multirow{2}{*}{$\begin{array}{l}\text { Content } \\
(\%)\end{array}$} & \multicolumn{2}{|c|}{ Mangalitsa } & \multicolumn{2}{|c|}{ Swedish Landrace } & \multicolumn{2}{|c|}{ Significance } \\
\hline & Male & Female & Male & Female & $\mathrm{G}^{1}$ & $\mathrm{~B}^{2}$ \\
\hline \multicolumn{7}{|c|}{ M. longissimus thoracis et lumborum } \\
\hline Moisture & $69.41 \pm 1.86$ & $70.85 \pm 1.84$ & $73.52 \pm 0.65$ & $73.85 \pm 1.65$ & ns & ns \\
\hline Fat & $6.73 \pm 0.46$ & $5.09 \pm 0.29$ & $1.71 \pm 0.51$ & $1.12 \pm 0.31$ & $*$ & $*$ \\
\hline Ash & $1.10 \pm 0.05$ & $1.00 \pm 0.10$ & $1.16 \pm 0.05$ & $1.18 \pm 0.03$ & ns & $*$ \\
\hline Protein & $22.73 \pm 0.94$ & $22.33 \pm 1.23$ & $23.56 \pm 0.24$ & $23.81 \pm 0.55$ & ns & ns \\
\hline \multicolumn{7}{|c|}{ M. gluteus medius } \\
\hline Moisture & $70.96 \pm 2.44$ & $71.92 \pm 2.22$ & $74.29 \pm 0.67$ & $74.54 \pm 0.79$ & ns & $*$ \\
\hline Fat & $6.81 \pm 0.38$ & $5.76 \pm 0.90$ & $1.83 \pm 0.66$ & $1.50 \pm 0.66$ & $*$ & $*$ \\
\hline Ash & $1.12 \pm 0.09$ & $1.05 \pm 0.10$ & $1.20 \pm 0.07$ & $1.20 \pm 0.04$ & ns & ns \\
\hline Protein & $21.95 \pm 1.15$ & $21.25 \pm 2.26$ & $22.67 \pm 0.97$ & $22.75 \pm 0.91$ & ns & ns \\
\hline \multicolumn{7}{|c|}{ M. triceps brachii } \\
\hline Moisture & $71.19 \pm 2.18$ & $71.73 \pm 0.37$ & $75.32 \pm 0.06$ & $74.52 \pm 0.25$ & ns & ns \\
\hline Fat & $6.16 \pm 0.47$ & $6.66 \pm 1.99$ & $1.85 \pm 0.33$ & $1.88 \pm 0.62$ & $*$ & $*$ \\
\hline Ash & $1.17 \pm 0.08$ & $1.15 \pm 0.06$ & $1.19 \pm 0.02$ & $1.18 \pm 0.08$ & ns & ns \\
\hline Protein & $21.46 \pm 1.10$ & $20.45 \pm 2.30$ & $21.61 \pm 0.36$ & $22.38 \pm 0.81$ & ns & ns \\
\hline
\end{tabular}


Pale, soft and exudative (PSE) pork was not an issue in the current trial as the $\mathrm{pH}$ measured in the muscles 45 minutes post mortem were all $<6.0$ (results not shown). The ultimate $\mathrm{pH}$ of all genotypes was 5.5-5.7, which is normally observed for pork (Table 3).

Table 3. Technological quality of meat from two pig breeds

\begin{tabular}{|c|c|c|c|c|c|c|}
\hline & \multicolumn{2}{|c|}{ Mangalitsa } & \multicolumn{2}{|c|}{ Landrace } & \multicolumn{2}{|c|}{ Significance } \\
\hline & Male & Female & Male & Female & $\mathrm{G}^{1}$ & $\mathrm{~B}^{2}$ \\
\hline \multicolumn{7}{|c|}{ M. longissimus thoracis et lumborum } \\
\hline $\mathrm{WHC}^{3}, \mathrm{~cm}^{2}$ & $12.81 \pm 2.40$ & $13.92 \pm 1.99$ & $12.86 \pm 1.24$ & $11.89 \pm 2.54$ & $\mathrm{~ns}$ & ns \\
\hline $\mathrm{pH}$ & $5.50 \pm 0.02$ & $5.51 \pm 0.03$ & $5.47 \pm 0.03$ & $5.53 \pm 0.05$ & ns & $\mathrm{ns}$ \\
\hline $\mathrm{SF}^{4}, \mathrm{~kg}$ & $5.66 \pm 1.09$ & $5.87 \pm 1.15$ & $6.40 \pm 0.68$ & $6.31 \pm 0.87$ & ns & $*$ \\
\hline $\mathrm{CL}^{5}, \%$ & $33.73 \pm 3.55$ & $31.55 \pm 2.75$ & $28.23 \pm 1.71$ & $27.91 \pm 2.66$ & ns & $*$ \\
\hline \multicolumn{7}{|c|}{ M. gluteus medius } \\
\hline WHC, $\mathrm{cm}^{2}$ & $11.08 \pm 1.99$ & $11.76 \pm 1.51$ & $12.21 \pm 1.31$ & $11.50 \pm 0.96$ & ns & $\mathrm{ns}$ \\
\hline $\mathrm{pH}$ & $5.59 \pm 0.10$ & $5.58 \pm 0.03$ & $5.61 \pm 0.07$ & $5.63 \pm 0.08$ & $\mathrm{~ns}$ & ns \\
\hline $\mathrm{SF}, \mathrm{kg}$ & $8.69 \pm 1.11$ & $9.40 \pm 1.92$ & $7.74 \pm 1.82$ & $7.04 \pm 1.25$ & ns & $*$ \\
\hline CL, \% & $39.02 \pm 2.87$ & $35.35 \pm 3.33$ & $27.39 \pm 1.82$ & $26.33 \pm 1.90$ & ns & $*$ \\
\hline \multicolumn{7}{|c|}{ M. triceps brachii } \\
\hline WHC, $\mathrm{cm}^{2}$ & $16.76 \pm 1.24$ & $17.04 \pm 2.07$ & $12.24 \pm 1.71$ & $14.28 \pm 1.39$ & $\mathrm{~ns}$ & $*$ \\
\hline $\mathrm{pH}$ & $5.51 \pm 0.07$ & $5.49 \pm 0.09$ & $5.62 \pm 0.02$ & $5.62 \pm 0.05$ & $\mathrm{~ns}$ & $\mathrm{~ns}$ \\
\hline $\mathrm{SF}, \mathrm{kg}$ & $7.75 \pm 1.05$ & $7.64 \pm 1.16$ & $6.23 \pm 0.84$ & $7.36 \pm 2.25$ & ns & $\mathrm{ns}$ \\
\hline CL, \% & $35.65 \pm 2.09$ & $37.51 \pm 2.20$ & $29.41 \pm 2.35$ & $31.59 \pm 3.32$ & ns & $*$ \\
\hline
\end{tabular}

According to Ouali et al. (1990) meat tenderness is affected by the origin and age of animals, their gender, breed, environmental conditions associated with the pre-slaughter stress, the slaughter itself as well as the time of meat ageing. An objective measure of tenderness is the force required to shear a piece of meat with low shear values being desirable. In this trial, breed had a significant effect on shear force (SF) values of cooked meat samples (Table 3). Mangalitsa fatteners had lower SF values for longissimus, but higher SF values for gluteus muscle, compared with Landrace. Meat shear force values were approximately the same between groups for triceps brachii muscle.

Cooking led to a systematic and significant loss of matter and the cooking yields differed depending on the muscle and cooking process (Gerber et al., 2009). 
In this trial, cooking weight loss was greater in muscles from Mangalitsa and statistically significant differences $(p<0.05)$ in this parameter were found for all analysed meat samples (Table 3 ).

Water holding capacity (WHC) of muscles were not influenced by gender or pig breed, except for $m$. triceps brachii, where it is determined that Landrace had better WHC compared with Mangalitsa (Table 3).

\section{Conclusion}

Compared to the Swedish Landrace, it was found out that the meat from the Mangalitsa had considerably higher intramuscular fat content in all analysed meat samples. As aspected, female fatteners had a significantly lower fat content when compared with male. Moisture content was statistically significantly higher in gluteus muscle of Landrace compared with Mangalitsa pigs. As for technological quality of meat, after cooking, meat from Mangalitsa had greater cooking weight loss compared to Landrace and also lower shear force values for longissimus, but higher shear force values for gluteus muscle. Gender had no statistically significant effect on technological meat quality.

From the obtained results it could be concluded that the autohthonous pig breeds, such as Mangalitsa, had favourable meat quality traits, which are very desirable for production of traditional meat products of high quality.

\section{Acknowledgement}

This paper is a result of the research within the project TR31081, financed by the Ministry of Education, Science and Technological Development of the Republic of Serbia.

\section{Uticaj pola i rase na fizičko-hemijske karakteristike mesa svinja}

N. Stanišić, M. Petrović, Č. Radović, M. Gogić, N. Parunović, S. Stajić, M. Petričević

\section{Rezime}

Ovaj ogled je imao za cilj da ispita razlike u fizičko-hemijskim karakteristikama mišića između muških i ženskih tovljenika rase mangulica i švedski landras. Istraživanje je sprovedeno na tri mišića: longissimus thoracis et 
lumborum, gluteus medius i triceps brachii. U poređenju sa švedskim landrasom, meso mangulica je imalo znatno veći udeo intramuskularne masti $(p<0,05)$. Najveći sadržaj intramuskularne masti utvrđen je kod muških tovljenika rase mangulica u gluteus medius-u (6,81\%), a najniži ko ženskih tovljenika rase švedski landras u longissimus-u (1,12\%). Što se tiče tehnološkog kvaliteta, meso mangulice je imalo veći gubitak mase tokom kuvanja u odnosu na meso landrasa i niže vrednosti sile sečenja (SF) za longissimus, ali veće vrednosti sile sečenja za gluteus mišić. Pol nije imao statistički značajan uticaj na parametre tehnološkog kvaliteta mesa. Na osnovu dobijenih rezultata može se zaključiti da meso mangulice ima veoma dobre parametre kvaliteta, a koji su poželjni pri proizvodnji tradicionalnih proizvoda od mesa.

\section{References}

ANTEQUERA T., LÓPEZ-BOTE C.J., CÓRDOBA J.J., GARCÍA C., ASENSIO M.A., VENTANAS J., GARCÍA-REGUEIRO J.A., DÍAZ I. (1992): Lipid oxidative changes in the processing of Iberian pig hams. Food Chemistry, 45, 105110.

AOAC (1990): Official methods of analysis. Washington, DC: Association of Official Analytical Chemists.

BEJERHOLM C., BARTON-GADE P.A. (1986): Effect of intramuscular fat level on eating quality of pig meat. Danish Meat Research Institute manuscript no. 720E: $1-5$.

ESTÉVEZ M., MORCUENDE D., CAVALOPEZ R. (2003): Physico-chemical characteristicsof $M$. Longissimus dorsi from three lines of free-range reared Iberian pigs slaughtered at $90 \mathrm{~kg}$ live-weight and commercial pigs: a comparative study. Meat Sci., 64, 499-506.

FRANCI O., BOZZI R., PUGLIESE C., ACCIAIOLI A., CAMPODONI G., GANDINI G. (2005): Performance of Cinta Senese and their crosses with Large White. 1 Muscle and subcutaneous fat characteristics. Meat Sci., 69, 545-550.

GERBER N., SCHEEDER M.R.L., WENK C. (2009): The influence of cooking and fat trimming on the actual nutrient intake from meat. Meat Science, 81, 148154.

GRAU R., HAMM R., BAUMANN A. (1953): Über das Wasserbindungsvermögen des toten Säugetiermuskels. I. Mitteilung. Der Einfluß des $\mathrm{pH}$ Wertes auf die Wasserbindung von zerkleinertem Rindermuskel. Biochem. Z., 325, 1-11.

LÓPEZ M.O., DE LA HOZ L., CAMBERO M I., GALLARDO E., REGLERO G., ORDÓÑEZ J.A. (1992): Volatile compounds of dry hams from Iberian pigs. Meat Science, 31, 267-277. 
OUALI A. (1990): Meat tenderisation: possible causes and mechanisms. A review. Journal of Muscle Foods, 1, 129-165.

PARUNOVIĆ N., PETROVIĆ M., MATEKALO-SVERAK V., RADOVIĆ Č., STANIŠIĆ N. (2013): Carcass properties, chemical content and fatty acid composition of the musculus longissimus of different pig genotypes. South African Journal of Animal Science, 43, 2, 123-136.

PETROVIĆ M., RADOVIĆ Č., PARUNOVIĆ N., MIJATOVIĆ M., RADOJKOVIĆ D., ALEKSIĆ S., STANIŠIĆ N., POPOVAC M. (2010): Quality traits of carcass sides and meat of Moravka and Mangalitsa pig breeds. Biotechnology in Animal Husbandry, 26, 21-27.

STANIŠIĆ N., LILIĆ S., PETROVIĆ M., ŽIVKOVIĆ D., RADOVIĆ Č., PETRIČEVIĆ M., GOGIĆ M. (2012): Proximate composition and sensory characteristics of Sremska sausage producedin a traditional smoking house. 6th Central European Congress on Food, CEFood2012, Novi Sad, Serbia, 23-26. May, Proceedings, 1319-1324.

STANIŠIĆ N., PETROVIĆ M., PARUNOVIĆ N., LILIĆ S., RADOVIĆ Č., GOGIĆ M., PETRIČEVIĆ M. (2013): Physicochemical properties of meat from three different pig breeds. International 57th Meat Industry Conference, June 1012., Belgrade, Serbia, Proceedings, 190-193.

VOLODKEVICH N.N. (1938): Apparatus for measurement of chewing resistance or tenderness of foodstuffs. Food Research, 3, 221-225.

ŽIVKOVIĆ D., RADULOVIĆ Z., ALEKSIĆ S., PERUNOVIĆ M., STAJIĆ S., STANIŠIĆ N., RADOVIĆ Č. (2012): Chemical, sensory and microbiological characteristics of Sremska sausage (traditional dry-fermented Serbian sausage) as affected by pig breed. African journal of biotechnology, 11, 16, 3858-3867. 